\title{
Is Integrated Reporting the silver bullet of financial communication? A stakeholder perspective from South Africa
}

\author{
Ronél Rensburg a , Elsamari Botha \\ a Communication Management Division, Centre for Communication and Reputation Management (CCRM), University of Pretoria, \\ Pretoria 0002, South Africa \\ b School of Management Studies, University of Cape Town, PO Box 60, Lincoln Street, Boston, Bellville, Cape Town 7350, South Africa
}

Keywords:

Integrated Reporting

Financial communication

Financial reports

King III

South Africa

\begin{abstract}
A B S T R A C T
Companies are being forced to critically re-evaluate how they communicate their financial information to stakeholders. Integrated Reporting, as mandated by the King III Report seeks to combine the reporting of financial and nonfinancial performance measures in a way that promotes corporate strategy. South Africa is leading the way in corporate governance and financial reporting with the first large-scale adoption of Integrated Reporting by listed companies. While there is a marked increase in financial communication from companies, it is not clear how all stakeholders use and value this information. The primary aim of this paper was to investigate how financial information is consumed within the ambit of the new financial reporting standards. Through a national online survey, this study found that very few stakeholders use the Integrated Reports as their main source of financial and investment information, and that these reports are seen as additional information. Annual and interim financial reports by companies are still the mainstay for corporate financial information. While stakeholders currently seldom use the Internet for financial information, they have indicated that they would increasingly prefer to do so. The paper concludes with a discussion of opportunities and challenges that future Integrated Reporting faces based on these findings.
\end{abstract}

\section{Introduction}

Global corporate reporting practices are undergoing radical changes as stakeholders make growing demands on companies and resources are becoming increasingly limited. Companies are being forced to critically re-evaluate how they can communicate financially, as transparently as possible, to all their stakeholders. Integrated Reporting (IR), as mandated by the King III Report on Corporate Governance for South Africa, seeks to combine the reporting of financial and non-financial performance measures in a way that promotes corporate strategy (Ernst \& Young, 2012). An Integrated Report is "a concise communication about how an organization's strategy, governance, performance and prospects lead to the creation of value over the short, medium and long term" (IIRC, 2013). Integrated Reporting is aimed towards providing benefits to a range of stakeholders and in particular to providers of financial capital allocation or investment decisions (IIRC, 2013). South Africa is leading the way with corporate governance as well as being the first country in the world to take on the implementation of Integrated Reporting (Ernst \& Young, 2012). In 2010, the Johannesburg Securities Exchange (JSE) made the Integrated

\footnotetext{
* Corresponding author. Tel.: +27 836707102; fax: +27 867197658.

E-mail addresses: ronel.rensburg@up.ac.za (R. Rensburg), elsamari.botha@uct.ac.za (E. Botha).
} 
Report a requirement for all listed companies, crowning South Africa as the first country to require Integrated Reporting on a large scale (SAICA, 2013).

Analysts predict that the Integrated Report will have a strong correlation to the resilience and ability of a business to create value in the short, medium and long term (IIRC, 2013). Since its inception, the reporting of both financial and nonfinancial information in a single document has grown as many companies are producing Annual Reports, Integrated Reports and separate Sustainability Reports (Hutton, 2004). Consequently, companies are passing on an ever-increasing amount of information to stakeholders.

While the initial objective of the Integrated Report was to communicate company financial and non-financial information to a broad range of stakeholders (IIRC, 2013), almost without exception, current Integrated Reports are aimed at investors (Watson, 2012). While there is mention made of other stakeholders, it is almost exclusively to show that the company is "an enlightened shareholder and a good corporate citizen and not directly for the needs of the other stakeholders" (Watson, 2012). It is this approach to financial communication that makes these reports inaccessible to the broader audience. Given the diversity of different stakeholder groups, it is understandable that companies mainly speak to investors. However, companies should be clearer in communicating what their overall philosophy is in respect to other stakeholders, as well as the value that they add to different and broader stakeholder groups.

At the same time, companies have to release ever-increasing amounts of information, making it difficult for investors to achieve and maintain an accurate valuation of a company's stock (Hutton, 2004), and near impossible for other stakeholders to do so. Hutton (2004) stated that standard disclosure practices left many companies releasing a great deal of data while conveying only limited understanding to outsiders. He proposed that the Integrated Report could possibly be the solution to this problem. After the initiation of Integrated Reporting, however, no further research has been done on whether these reports have added value to stakeholders' knowledge of the company and its activities. Little is still known about how investors and other stakeholders consume financial information, whether the Integrated Report has replaced or supplanted other stakeholder sources of company information, if stakeholders and investors understand the information contained in these reports and which factors influence how stakeholders consume their financial information. These changes in financial reporting have been paired with an increasingly complex economic and business environment in South Africa.

This study takes an exploratory look at financial communication in South Africa, with a particular focus on the Integrated Report. The article begins with a view of the social, political and economic climate within which these new financial communication standards had been released, where after financial reporting in South Africa is briefly discussed. This is followed by a description of the Integrated Reporting Standards. The methodology of the study is then described, followed by a discussion of the findings and their managerial implications. The article concludes with a discussion of the limitations of the study, as well as future research implications.

\section{The South African context}

South Africa has a unique economy. It is home to eleven official languages and its political history of apartheid still has strong undercurrents in today's economic environment. Poverty is rife and inequality in the workplace is ever present, whilst acceptable education levels are still found wanting. Out of this population of approximately 50 million, $79 \%$ is made up of black Africans, whilst $10 \%$ are white. Whites make up $12 \%$ of the workforce, but hold $65 \%$ of the top and executive management positions in companies across all economic sectors, indicating a substantial inequality in the workplace (StatsSA, 2011). In a recent community survey, it was found that $8 \%$ of households have no income and that a further $22 \%$ live with less than R10 000 per year (AMPS, 2011). On the other side of the scale $9 \%$ of households have an income larger than R300 000 per year (AMPS, 2011).

With regards to education, $22 \%$ of people older than 20 have not had any schooling, with only $12 \%$ having access to higher education. The unemployment rate is reported as being close to 30\%, indicating that the bulk of the economy is carried by only $70 \%$ of those able to work (AMPS, 2011). On the other hand, the South African stock market rose $23 \%$ in 2012 (Anon, 2013; Department of Trade and Industry, 2013). South Africa ranks first in the world in terms of platinum output, second in palladium output, third in gold output, sixth in coal output and ninth in wool output (Department of Trade and Industry, 2013). It has officially become part of the BRICS countries in December 2010, making it one of the key emerging economies in the world (Conway-Smith, 2011), even though its growth is slower compared to the other BRICS countries (Brazil, Russia, India and China).

With a particular focus on financial communication to the general public, there had been approximately 160000 copies of economically orientated publications, aimed at the end consumer and not business-to-business, in circulation during the first quarter of 2010 (AMPS, 2011). These are predominantly published in English, which is first language to less than 10\% of the South African population. Of the 11 official languages, IsiZulu is the first language of the majority of the population, but this is still only in $22 \%$ of the households (AMPS, 2011). IsiZulu then, is the first language of most South Africans (22\%), followed by isiXhosa (16\%), Afrikaans (13.5\%) and English (9.6\%) (StatsSA, 2011). English is, however, the language most commonly shared by South Africans, as well as the common language of business in the country. These figures suggest, though, particularly due to the complex nature of most financial reports, that these reports might not be well understood by the general population. 


\section{Financial reporting in South Africa}

A company's market value is a key determinant of its future success as it affects its ability to raise capital, recruit and retain key employees, and make strategic acquisitions (Hutton, 2004). Well-informed investors are a necessity for a company to achieve and maintain accurate valuations of its stock (Hutton, 2004). The primary objective of financial reporting, from a management point of view, is to ensure stakeholders that the company can produce respectable earnings per share (EPS) ratio, both consistently and reliably (Graham, Harvey, \& Rajgopal, 2005). This stimulates investment in a company. As analysts and investors alike are predominantly risk averse, researchers suggest that company earnings is the preferred metric for investors, as perceived by CFOs (Graham et al., 2005). By meeting financial targets, company leaders are able to maintain healthy stock prices, build confidence in both the future prospects and current viability of investing in the company and build a credible reputation for the governance of the company.

The International Financial Reporting Standards (IFRS) were globally introduced in 2001 to enable the comparison of businesses internationally (IIRC, 2013). IFRS financial statements consist of a Statement of Financial Position, a Statement of Comprehensive Income, a Statement of Changes in Equity, a Cash Flow Statement and a summary of significant accounting policies, as well as comparative information for the prior reporting period (PWC, 2013). South Africa has adopted the IFRS, at the time ahead of many European counterparts, and all companies listed on the JSE are required to adhere to these standards (Graham et al., 2005). Graham et al. (2005) state that South Africa adopted the IFRS to make it more attractive to foreign investors, to enhance the credibility of South African companies in the global market and to ease the burden of multi-listed companies to report financially on different international standards. As South Africa was one of the early adopters of the IFRS, it has allowed international companies to observe how IFRS have been applied to local companies.

In addition to adopting the IFRS standards, South Africa is also one of the leading countries in global Integrated Reporting (Ernst \& Young, 2012). The Integrated Report (now known as IR) is a concise communication of various key short, medium and long term financial and non-financial indicators and should be prepared in accordance with the International Integrated Reporting Council's framework (IIRC, 2013).

\section{Integrated Reporting (IR) in South Africa}

In March 2010, the Johannesburg Securities Exchange (JSE) adopted the King III Report on Corporate Governance principles as part of its listing requirements, and consequently required of listed companies to issue Integrated Reports in future (IIRC, 2013). When the first King Report on corporate governance was published (King I, n.d.), it recommended standards of conduct for boards and directors of listed companies, banks and state-owned enterprises. It advocated an approach to governance that involved all stakeholders and not only shareholders. In 2002, however, Judge Mervyn King (the architect of the King reports) advocated that the King I Report be revised to include new sections on sustainability, the role of the corporate board, and risk management (Berwick, 2001; King II, 2002). The King III Report saw the light in 2009 and the revised rendition suggested that companies should report on governance, strategy and sustainability in an integrated way as opposed to reporting on these elements separately. The report stated that strategy, risk, performance and sustainability have become inseparable. And it was in this report, that there was a call for companies to create an Integrated Report (SAICA, 2013). Integrated Reports should provide a greater context for performance indicators, they should clarify how relevant information fits into a business and the long-term strategy of the company and should ultimately benefit a range of stakeholders. According to West (2009) it is exactly this stakeholder approach of the King reports that is critical for the continued development of the country and the region. South African governance has broadly followed Anglo-American examples, with the notable exception of the stakeholder approach in the King reports (West, 2009). This means that, in principle, not only a select few but all stakeholders should understand and have access to key investment information.

Since these new reporting standards have been introduced, the majority of research has focused on how well companies are reporting their financial results in an integrated manner. For example, Watson (2012) states that in general companies did a good job of making their Integrated Reports accessible, but that there were various obstacles to releasing Integrated Reports. These obstacles included limited guidance, few published examples and uncertainty arising from potentially conflicting guidance (Watson, 2012). A few studies, however, have looked at how well these reports have been received by various investors and other stakeholders. And whether these reports could indeed be the "silver bullet" to financial reporting by companies. Even though one of the objectives of the new reporting standards is to make company information available and accessible to the broader public, very few (if any) studies have tested how the general public is accessing and using this information. More importantly, there is little information whether these reporting standards have increased stakeholders' understanding of the financial information communicated to them.

Given the changes in financial reporting standards, the early adopter role that South Africa is playing with regards to Integrated Reporting, but also the challenging context of South Africa where all these phenomena are occurring, this study aimed to take an exploratory look at the general public's perception of financial reporting in South Africa.

\section{Methodology}

An exploratory research design had been followed in which an online survey was utilized. The target population of this study was very broadly defined as the general public, with a particular focus on those consuming financial information. With this target population in mind, the only research method that would allow the authors: 
(1) access to respondents from across South Africa, and

(2) target respondents who had at least a working knowledge or use of financial information, was an online survey. The major advantages of self-administered email or online surveys, in this context, had been its speed, respondent participation and cooperation (Zikmund, Babin, Carr, \& Griffin, 2013), as well as its access to the target population (Malhotra, 2010).

The major disadvantages of the online survey include self-selection error, and sample representativeness (Zikmund et al., 2013). The latter being of concern, as not all South Africans have access to the Internet. However, with the exploratory nature of this study, and with over 4.6 million people in South Africa who accessed the Internet in the past $24 \mathrm{~h}$ (AMPS, 2011), the authors decided to use this method. The authors further believed that they would get a relatively substantial representation of the different population groups, as of the 4.6 million people who accessed the Internet in the past $24 \mathrm{~h}, 51 \%$ were black, $33 \%$ white, $9 \%$ coloured and $7 \%$ Indian (AMPS, 2011).

This online survey was made available to respondents on South Africa's leading online financial news outlet, and convenience sampling was consequently used. The link to the website remained open for two weeks in November 2012.

\section{Findings}

As a non-probability sampling technique was used, and respondents had to tap into the online survey, it was difficult to calculate a response rate (Malhotra, 2010). A total of 421 respondents completed the online survey. The sample was slightly skewed towards white males, with $61 \%$ of respondents being male, and $87.6 \%$ being white (as opposed to $4 \%$ being coloured and $1 \%$ black). Overall, around $77 \%$ of respondents were over the age of 40 with the majority (36\%) being between the ages of 56 and $69-8 \%$ were 25 or younger, $15 \%$ were between 26 and $40,18 \%$ were between 56 and 69 years, and $12 \%$ were older than 70 years. These demographics were comparable to the typical Internet user. As one of the non-OECD countries, South Africa has the ninth highest Internet penetration in the world, and users are typically male (63\% on average), employed (62\%) and 33 years old (Chen, Boase, \& Wellman, 2002). Chen et al. (2002) found that these Internet users also, in addition to their online consumption, typically still used traditional print media (around 90\% of them), and this was consistent with the findings in this study. The primary aim of this article, however, was to investigate how financial information is consumed with new financial reporting standards. Using an online financial news platform provided the authors with access to stakeholders who regularly use (or at least access) financial information.

The following sections discuss the findings from the online survey by first looking at the respondents' general media usage and preferences with regards to financial information, and then addressing their use of the integrated financial reports. Thereafter the key predictors to the use of financial reports are described, followed by an investigation into what improves stakeholders' understanding of financial reports. Lastly, the relationship between education and financial information consumption is investigated.

\subsection{Media usage and preferences for financial communication}

Respondents were asked to what extent they currently use different sources of information and communication channels to make investment decisions, and they were also asked which sources and channels they would like to use in future investment decisions, if they were forced to choose one. Table 1 reports on the first question.

Respondents were asked to rate the extent to which they currently use the above-mentioned sources of information on 5 -point Likert scale (from $1=$ never, to $5=$ all of the time). On average, the respondents indicated that they only sometimes

Table 1

To what extent do you consult the following sources of financial information?

\begin{tabular}{|c|c|c|c|}
\hline \multicolumn{4}{|c|}{ Sources of information respondents currently consult } \\
\hline Group & Measured & Mean & Std. Dev. \\
\hline \multirow[t]{4}{*}{ The company itself } & Annual Financial Reports of the companies & 3.23 & 1.23 \\
\hline & Interim financial reports by the companies & 2.94 & 1.18 \\
\hline & Integrated Reports by the companies & 2.87 & 1.19 \\
\hline & The officials of the involved companies & 2.69 & 1.12 \\
\hline \multirow[t]{3}{*}{ Experts } & Financial investment programmes on radio and/or television & 3.03 & 1.06 \\
\hline & Advice from financial advisors & 1.46 & 0.82 \\
\hline & Lectures or talks by specialists & 2.38 & 1.10 \\
\hline \multirow[t]{2}{*}{ News sources } & Financial print media (mainstream newspapers and magazine articles) & 3.44 & 1.06 \\
\hline & International news, sources and markets & 3.53 & 1.15 \\
\hline \multirow{4}{*}{ Social and reference networks } & Advice by community and opinion leaders & 3.15 & 1.21 \\
\hline & Advice of friends/family/acquaintances & 2.57 & 1.09 \\
\hline & Advice of colleagues & 3.29 & 1.15 \\
\hline & Politicians & 1.46 & 1.01 \\
\hline \multirow[t]{2}{*}{ Media } & The Internet & 2.23 & 1.12 \\
\hline & Social media & 2.99 & 1.11 \\
\hline Other & Notices from the JSE & 3.32 & 1.080 \\
\hline
\end{tabular}


Table 2

Through which of the following sources would you like to receive your financial information?

\begin{tabular}{|c|c|c|c|}
\hline \multicolumn{4}{|l|}{ Preferred sources of communication } \\
\hline & Frequency & Valid \% & Cumulative \% \\
\hline Financial reports & 35 & 9.9 & 9.9 \\
\hline Columns by financial journalists & 28 & 8.0 & 17.9 \\
\hline Radio talks & 8 & 2.3 & 20.2 \\
\hline Television & 18 & 5.1 & 25.3 \\
\hline Business media & 43 & 12.2 & 37.5 \\
\hline Company itself & 52 & 14.8 & 52.3 \\
\hline Economists and business analysts & 61 & 17.3 & 69.6 \\
\hline Friends and family & 7 & 2.0 & 71.6 \\
\hline Financial training programmes & 23 & 6.5 & 78.1 \\
\hline Colleagues & 1 & 0.3 & 78.4 \\
\hline Notices from the JSE & 26 & 7.4 & 85.8 \\
\hline Financial advisors & 50 & 14.2 & 100.0 \\
\hline Total & 352 & 100.0 & \\
\hline
\end{tabular}

(around 3) used most of the reports from companies, including the Integrated Report. Of these company reports, it appeared that the Annual Report was used more often, although respondents also only sometimes (mean =3.23) used this report. Surprisingly, respondents indicated that they rarely used advice from financial advisors (mean =1.46) and the Internet (mean $=2.23$ ). Advice from colleagues was used more often than both of these sources of information (mean $=3.29$ ).

Respondents were heavily dependent on news sources, in particular financial print media (mean $=3.44$ ) and international news sources ( mean $=3.53$ ). Even though respondents stated that they currently do not use financial advisors and the Internet for investment decision information, they indicated that they would like to do so in future (see Table 2).

In Table 1, respondents stated that they sometimes have depended on their colleagues' advice to make financial decisions, that they do not use the Internet, or the advice of financial advisors.

When asked from where they would prefer to get their investment information, the majority (17.3\%) stated that they want it from economists and business analysts, followed by the company itself (14.8\%), financial advisors (14.2\%) and business media (12.2\%). Only about $10 \%$ of the respondents stated that they would like to get their investment information from financial reports.

When asked through which medium they would like to receive this information, over $60 \%$ of respondents stated that they would like to get it from the Internet (see Table 3).

A rise in the popularity of the Internet as a financial communication channel, however, did not supplant traditional print media. Seventeen percent of respondents indicated that they still preferred to consult printed media to make their financial decisions. Respondents received almost $89 \%$ of their investment decision information from these two sources.

Respondents were also asked which financial report, or component of the financial report, is most important to them. The majority (34\%) indicated that they use the Annual Financial Report, 13\% said they looked at the Condensed Balance Sheet and $10 \%$ said that the Executive Summary is the most important. Only 5.6\% of respondents stated that the Integrated Report is the most important component of a company's financial results.

From the above findings it appears that, even with the introduction of improved accounting standards (IFRS) and the Integrated Report, not many respondents are currently making use of these reports from companies. The following section specifically looks at respondents' use of financial reports.

Table 3

Which communication channel would you prefer to get your investment information from?

\begin{tabular}{lccc}
\hline Preferred communication mediums & & & \\
\hline & Frequency & Valid \% & Cumulative \% \\
\hline Printed media & 61 & 17.3 & 17.3 \\
Radio & 8 & 2.3 & 19.6 \\
TV & 12 & 3.4 & 23.0 \\
Internet & 217 & 61.6 & 84.7 \\
Mobile & 6 & 1.7 & 86.4 \\
Group information sessions & 9 & 2.6 & 88.9 \\
Interpersonal communication & 14 & 4.0 & 92.9 \\
Financial training workshops & 22 & 6.3 & 99.1 \\
Other & 3 & 0.9 & 100.0 \\
Total & 352 & 100.0 & \\
\hline
\end{tabular}


Table 4

Model fit statistics for stepwise regression on the use of financial reports.

\begin{tabular}{|c|c|c|c|c|c|c|}
\hline \multicolumn{7}{|c|}{ Stepwise regression model } \\
\hline & Model & $R$ & $R$ square & & |uare & Std. error of the estimate \\
\hline \multirow[t]{2}{*}{ Model fit statistics } & & 0.65 & 0.43 & & & 23.85 \\
\hline & & & Sum of squares & df & Mean square & $F$ \\
\hline \multirow{3}{*}{ ANOVA } & Regression & & $119,305.20$ & 3 & $39,768.40$ & 69.94 \\
\hline & Residual & & $161,475.25$ & 284 & 568.58 & Sig. \\
\hline & Total & & $280,780.44$ & 287 & & 0.00 \\
\hline
\end{tabular}

\subsection{Key predictors of the use of financial reports}

Seventeen percent of respondents stated that they are not able to understand any information contained in company financial reports, as opposed to $12 \%$ who stated that the information was simply not relevant, and $71 \%$ who stated that the information was indeed relevant. Even though the majority stakeholders indicated here that the information in financial reports were relevant, few of them believed that the information was adequate. Only $45 \%$ of respondents believed that the information contained in financial reports was adequate, $34 \%$ believed that it was not, and $21 \%$ simply did not know if the information was adequate. When cross-tabulated (Chi-square $p$-value $<0.05$ ) the following was found: $38 \%$ of respondents felt that the information contained in financial reports was both relevant and adequate for investment decisions, $25 \%$ felt that it was relevant but not adequate, and $12 \%$ indicated that they did not know if the information was relevant or adequate. The finding that financial reports were seldom used to make financial decisions was reinforced by the finding that respondents, on average, used information obtained from financial reports in around 38\% of their investment decision-making.

Based on these findings, further analysis was done into which factors contributed most to the use of financial reports for investment decision-making. As this is an exploratory study, stepwise regression was used where the dependent variable was the extent to which financial reports are used in investment decisions, and the independent variables were:

(1) all the sources that respondents consulted when making a financial decision;

(2) the extent to which the components of a financial report are read, and

(3) the respondents' level of understanding of each of these components.

Three models were fitted and the third model was used because it had the best model fit statistics. The following model was obtained (Tables 4 and 5 ):

The fitted regression model was significant ( $p$-value $=0.00, F$-value $=69.94$ ) with an $R$-square value of 0.43 . All three predictors loaded onto the model at a $1 \%$ level of significance.

Integrated Reports did not contribute towards the respondents' use of financial reports in investment decisions. The greatest contributor to this dependent variable was the extent to which the Annual Financial Report was read. This predictor had the greatest impact (Beta $=0.34$ ) on the respondents' use of financial reports in investment decisions, followed by the extent to which they understand the Interim Report $(B e t a=0.29)$ and the extent to which the Condensed Statement of Changes in Equity is read (Beta $=0.24$ ). When respondents were asked directly whether they read the condensed statement regarding the changes in equity, few rated this as an important component of financial reports (only $4.5 \%$ ). However, the regression suggests that respondents, who typically use financial reports to make investment decisions, do consult these three sections of the financial reports (and do not necessarily consult the Integrated Report).

Whereas this section looked at the respondents' utilization of financial reports, the following section investigates their comprehension thereof.

Table 5

Coefficients for stepwise regression on the use of financial reports.

\begin{tabular}{|c|c|c|c|c|c|}
\hline & \multicolumn{2}{|c|}{ Unstandardized coefficients } & \multirow{2}{*}{$\begin{array}{l}\text { Standardized coefficients } \\
\text { Beta }\end{array}$} & \multirow[t]{2}{*}{$t$} & \multirow[t]{2}{*}{ Sig. } \\
\hline & $B$ & Std. Error & & & \\
\hline Constant & -30.14 & 5.00 & & -6.03 & 0.00 \\
\hline $\begin{array}{l}\text { Extent to which the Annual Financial Reports is } \\
\text { consulted to make investment decisions }\end{array}$ & 8.44 & 1.22 & 0.34 & 6.91 & 0.00 \\
\hline Understanding of Interim Financial Report & 4.88 & 0.85 & 0.29 & 5.75 & 0.00 \\
\hline $\begin{array}{l}\text { Extent to which the Condensed Statement of } \\
\text { Changes In Equity, from the financial report, } \\
\text { is read }\end{array}$ & 10.58 & 2.25 & 0.24 & 4.71 & 0.00 \\
\hline
\end{tabular}

*Dependent variable: the percentage of times respondents have used financial reports to make investment decisions. 


\subsection{The key predictors of stakeholders' understanding of financial reports}

Based on the above findings, summated scales were created for how well respondents, on average, understood financial reports (7-point Likert scale) and the extent to which they read financial reports (3-point Likert scale). Different size scales were used as a measure to combat common method variance (Podsakoff, MacKenzie, Lee, \& Podsakoff, 2003).

Respondents' general understanding of financial reports averaged 4.52 (standard deviation=1.77) where "1" indicated that they did not understand financial reports at all, and "7" that they completely understood the reports. Most respondents indicated that they, on average, superficially read all the components of financial reports with an average of 2.08 (standard deviation = 0.57 ), where "1" indicated that they did not read it at all, " 2 " that they read it superficially, and "3" that they read it thoroughly. Another stepwise regression was done to determine the key predictors of respondents' understanding of financial reports. As previous studies mention demographic variables as key influencing factors in financial literacy, all the measured demographic variables were included in the analysis.

Only one model was fitted $(p=0.00, F$-value $=91.03$ ). The $R$ value was 0.67 , and the $R$-square value was 0.44 . Each predictor loaded significantly onto the model. The following model was fitted:

Understanding of financial reports $=0.51$ (extent to which financial reports are read)

+0.15 (percentage time that you have used financial reports in investment decisions) +0.18 (level of education).

The more respondents read and used the financial reports to make investment decisions, the more they understood them. Significantly, however, was the key role that education played in respondents' understanding of financial reports. As education was found to play a role in respondents' consumption of financial reports, the authors also investigated how (i.e. through which media) respondents with different education backgrounds consumed financial reports.

\subsection{The association between education and media usage in financial communication}

Correspondence analysis was used to investigate the association between the media through which respondents preferred to receive their financial communication, and their level of education.

Four factors emerged with $18 \%$ inertia ( $p$-value $=0.52$ ). The high $p$-value could be attributed to the slightly skewed sample with regards to education. The respondents of the study were, in general, highly educated where the majority of respondents (31.5\%) had a postgraduate degree. Only $7 \%$ did not complete school, $27.5 \%$ had a first degree, $21.5 \%$ a diploma or certificate, and $17.5 \%$ had completed secondary school.

Fig. 1 provides an illustration of the association between level of education and media usage for investment decisionmaking. When looking at the sources of information through which respondents preferred to receive their financial information only, it was evident that so-called expert opinions (in the business media, financial reports, through financial advisors, notices from the JSE, economists and business analysts and messages from the company itself) clustered together. The furthest removed from this cluster was advice from friends and family, advice from colleagues and radio talks. Financial training programmes were also not considered a part of this "expert cluster".

With the respondents' level of education, those with degrees and secondary school education grouped together, and respondents who did not complete school was far removed from this grouping. Finally, in looking at the association between these two variables, the following pattern emerged (see Fig. 1).

Respondents that did not complete their secondary school, was completely removed from most sources of financial information with the closest source being radio talks. Those who had finished secondary school appeared to primarily use advice from colleagues, but grouped closer to the "expert opinion" sources. Those with graduate and postgraduate degrees, on the other hand, neatly grouped together with valuable investment decision sources like financial advisors and business media. Respondents with diplomas and certificates preferred economists and business analysts, as well as columns by financial analysts, the company itself and financial advisors. The greatest users of financial reports appeared to be respondents with postgraduate degrees.

In the South African population, however, only $12 \%$ of the population has tertiary education and higher degrees. Approximately $28 \%$ completed high school, $33 \%$ completed some (but not all) secondary school, and the remaining $25 \%$ completed primary school at most. Nine percent has no schooling at all (StatsSA, 2011). This raises the question of how accessible and understandable the current financial reporting system is to the general population and also provides a glimpse into the challenges that face companies in reporting their financial and non-financial results.

\section{Discussion and managerial implications}

The above analyses provided an exploratory look at various stakeholders' consumption of financial reports and financial information. Stakeholders are exposed to an increasing amount of financial communication that could either hamper or assist in their decision-making. Over 160000 copies of economically oriented publications are released to consumers in South Africa every quarter. The most common mode of information disclosure by companies is still the printed Annual Report, but companies are increasingly urged to use the Internet as their main source of communication to stakeholders 


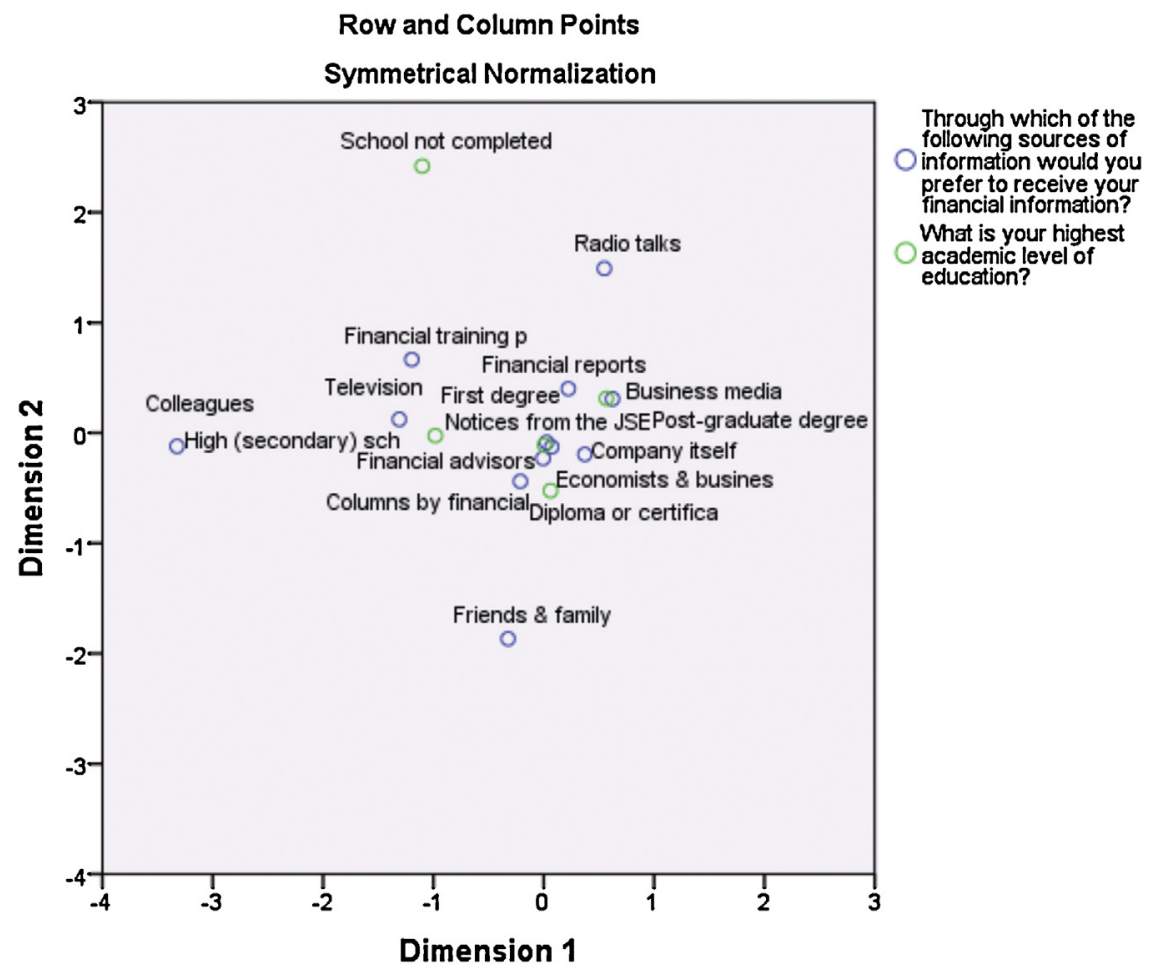

Fig. 1. Correspondence analysis of level of education and media where respondents preferred to receive financial information.

(Debreceny, Gray, \& Rahman, 2002). Communicating company information through the Internet will become a key focus of companies in future. Debreceny et al. (2002) found that South African online financial reporting, on average, consisted of static websites with only summary financials. They also state, however, that stakeholders are now more often expecting these sites to be dynamic and interactive and have extensive information. Watson (2012) states that South African companies are increasingly making better use of the Internet to provide stakeholders with financial information regarding the company. Even though respondents are not currently using the Internet extensively to access information about the company and financial reports from the company, they indicated that they would like to do so in future. Watson (2012) mentions particular effective cases where the Internet was used to give users the ability to construct their own financial report (depending on what was of particular interest to them). Consumer co-creation can be a valuable tool in the financial reporting arena and more companies should strive to customize stakeholders' financial information based on the particular financial information needs of the stakeholders. Stakeholders should be able to create their own dashboard of financial information, of which the Integrated Report is a key resource.

Watson (2012) also states that many companies have taken a "wait and see approach" to the Integrated Report and this observation became evident in this study's findings. Greater focus should be placed on the value that the Integrated Report can offer the general public as well as investors - therefore all stakeholders of a company. These reports should be simplified and made comprehensible and legible to a broader stakeholder audience. Watson (2012) stated that the most successful Integrated Reports were the simplest ones. It should decrease printed news space, but also add to the diversification of various media platforms (for examples navigation opportunities to various related websites, etc.). If the initial objective of the Integrated Report initially had been to decrease and summarize all the financial and non-financial information released by companies, it has now only added to the information. Stakeholders need to understand the importance of these reports, how to use them, and the value that they can add. One way to do this is to get the top management of companies to endorse the Integrated Report. Many companies do not make it clear that their board of directors endorse the Integrated Report (Watson, 2012). Watson (2012) reiterates that if the Integrated Report is to achieve its status of being the primary report of financial information by a company, then it is essential that the company directors make it clear that they endorse the contents thereof. In order for the Integrated Report to serve its purpose, companies should be clear on its use. Training programmes, practice notes and information sessions (even space and time in the traditional mainstream media) would serve stakeholders well in this regard. Management can also supplement mandated financial reporting with voluntary communication that highlights company value drivers and helps investors and other stakeholders understand both the company's strategic objectives and management's progress in meeting those objectives (Hutton, 2004).

Another challenge for companies, is to communicate the Integrated Report in such a way that not only highly educated people with degrees can read and use its information. This study found that the respondents that typically used and 
understood financial reports were those with postgraduate degrees. Further research needs to be conducted into why this continues to be a phenomenon. Is it because of the readability ease or difficulty of these reports? Are they understandable? Is financial communication readily accessible to all stakeholders? These findings suggest that financial communication - in general - by companies still has a long way to go in terms of making financial and investment information accessible to the general public. This complex issue involves factors like education, poverty, governance, leadership and economic challenges, and companies alone cannot be blamed for the lack of comprehension of financial communication by the general public.

\section{Conclusion}

One of the greatest challenges facing companies today is how to concisely communicate valuable investment information to all stakeholders, via the communication channels or platforms that the latter prefer, and in so doing without great cost to the company. Where financial officers have typically been responsible for financial communication with investors, public relations and communication management professionals in these companies could now take the lead to more effectively communicate to a broader range of stakeholders.

\section{References}

AMPS. (2011). Community survey. In The South African all media and products survey via Eighty20. Retrieved from http://www.eighty20.co.za/databases/index.cgi

Anon. (2013). Fast facts \& quick stats about South Africa. In South Africa - The good news. Retrieved from http://www.sagoodnews.co.za/ fast_facts_and_quick_stats/index.html

Berwick, G. (2001). The executive guide to insurance and risk management (2nd ed.). Australia: QR Consulting.

Chen, W., Boase, J., \& Wellman, B. (2002). The global villagers: Comparing internet users and uses around the world. In Internet in everyday life.

Conway-Smith, E. (2011). South Africa to be a BRIC: South Africa invited to join the world's fastest growing economies - But growth is slow. In Global post. Retrieved from http://www.globalpost.com/dispatch/south-africa/110107/south-africa-be-bric

Debreceny, R., Gray, G. L., \& Rahman, A. (2002). The determinants of Internet financial reporting. Journal of Accounting and Public Policy, 21(4-5), 371-394. http://dx.doi.org/10.1016/S0278-4254(02)00067-4

Department of Trade and Industry. (2013). South Africa: Investor's handbook 2012/2013 - Deloitte. Retrieved from http://www.deloitte.com/assets/Dcom-SouthAfrica/Local\%20Assets/Documents/DTI-Investing-in-SA.pdf

Ernst \& Young. (2012). Excellence in Integrated Reporting Awards 2012. In Ernst E Young: Quality in everything we do. Retrieved from http://www.ey.com/ZA/en/Services/Specialty-Services/Climate-Change-and-Sustainability-Services/2012-EIR-main-page

Graham, J. R., Harvey, C. R., \& Rajgopal, S. (2005). The economic implications of corporate financial reporting. Journal of Accounting and Economics, 40(1-3), 3-73. http://dx.doi.org/10.1016/j.jacceco.2005.01.002

Hutton, A. (2004). Beyond financial reporting: An integrated approach to disclosure. Journal of Applied Corporate Finance, 16(4), 8-16. http://dx.doi.org/10.1111/j.1745-6622.2004.00003.x

IIRC. (2013). Integrated reporting. In The International Integrated Reporting Council. Retrieved from http://www.theiirc.org/

King I (n.d.). King I Report - Institute of Directors in Southern Africa (IoDSA). Retrieved from https://iodsa.siteym.com/store/view_product.asp?id= 1418139\&hhSearchTerms=King+and+Report+and+I

King II. (2002). King report on corporate governance for South Africa. Retrieved from http://www.mervynking.co.za/downloads/CD_King2.pdf

Malhotra, N. (2010). Marketing research (6th ed.). USA: Prentice Hall.

Podsakoff, P. M., MacKenzie, S. B., Lee, J.-Y., \& Podsakoff, N. P. (2003). Common method biases in behavioral research: A critical review of the literature and recommended remedies. Journal of Applied Psychology, 88(5), 879-903.

PWC. (2013). Global | IFRS disclosure checklist 2012. In PricewaterhouseCoopers Inform. Retrieved from https://pwcinform.pwc.com/inform2/show?action=informContent\&id=1232052010126242

SAICA. (2013). Summary of report on governance for South Africa - King III 2009. The South African Institute of Chartered Accountants. Retrieved from http://www.auditor.co.za/Portals/23/king\%20111\%20saica.pdf

StatsSA. (2011). Census 2011. Retrieved from http://www.statssa.gov.za/Census2011/Products.asp

Watson, A. (2012). Integrated reporting - General impressions. In Ernst E Young's Excellence in Integrated Reporting Awards. South Africa: Ernst \& Young. Retrieved from http://www.ey.com/ZA/en/Services/Specialty-Services/Climate-Change-and-Sustainability-Services/2012-EIR-main-page

West, A. (2009). The ethics of corporate governance: A (South) African perspective. International Journal of Law and Management, 51(1), 10-16. http://dx.doi.org/10.1108/17542430910936637

Zikmund, W. G., Babin, B. J., Carr, J. C., \& Griffin, M. (2013). Business research methods (9th ed.). Canada: South-Western Cengage. 